EESTI NSV TEADUSTE AKADEEMIA TOIMETISED. 30. KOIDE GEOLOOGIA. 1981, NR. 3

ИЗВЕСТИЯ АКАДЕМИИ НАУК ЭСТОНСКОИ ССР. ТОМ 30 ГЕОЛОГИЯ. 1981, № 3

\title{
РАСПРЕДЕЛЕНИЕ ОСТАТКОВ ИСКОПАЕМЫХ ОРГАНИЗМОВ (МАКРОФОССИЛИИ И ДЕТРИТА) В СРЕДНЕМ ОРДОВИКЕ ПРИБАЛТИКИ
}

Среднеордовикские отложения Прибалтики богаты остатками ископаемых организмов, которые в виде целых или частично поврежденных скелетов представляют интерес для палеонтологов, а в виде органогенно-обломочного материала (детрита) - прежде всего для литологов. В данной статье впервые представлены результаты сравнительного изучения распространения и группового состава макроостатков организмов (макрофоссилий) и детрита, содержащихся в среднеордовикских породах Северной и Средней Прибалтики. Целью проведенных исследований было выяснение соотношений между макрофоссилиями и их детритом и изучение характера изменений этих соотношений (как по площади, так и по вертикали). Полученные сравнительные данные позволяют уточнить значение отдельных групп организмов в составе среднеордовикской экосистемы, определить их роль в образовании органогенно-обломочного материала и могут быть применены при фациальном анализе (Аалоэ, 1977). Аналогичные исследования проведены также американскими геологами (Smosna, Warshauer, 1978).

Представленный в данной статье материал происходит из кернов буровых скважин, при этом в отношении макрофоссилий наиболее детально изучены разрезы по линии Кыргессааре-Рапла-Кандава (рис. 1). Вопросы расчленения и корреляции этих разрезов изучались ранее (Кала и др., 1962; Мянниль, 1966, 1972, 1976; Вингисаар, 1971;

Рис. 1. Схема расположения буровых скважин. Под названием скважины приведено общее число образцов, содержащих макрофоссилии, в скобках - средний интервал между образцами $(M)$. $1 a$ - северная структурно-фациальная зона, 16 - переходная полоса, 2 - осевая структурнофациальная зона (по Пылма, 1967, с дополнениями).

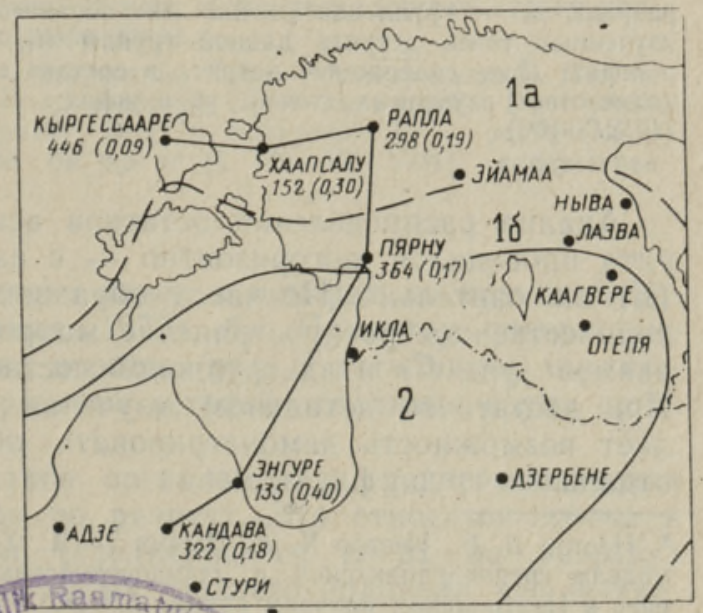

कNSV T.A 
Пылма, 1972а, б; Нестор и др., 1976*). Весь керновый материал из буровых скважин на отмеченной линии был изучен послойным опробованием с учетом максимального извлечения макрофоссилий. Таксономический состав макрофоссилий в каждом образце определяли в ходе специальных палеонтологических исследований. При этом брахиоподы, трилобиты и отчасти иглокожие были определены Л. Хинтс, а частично Р. Мяннилем на видовом и родовом уровнях, остальные группы в преобладающем большинстве на уровне типов и классов. Для целей данной работы достаточно было рассматривать макрофоссилии на уровне крупных таксономических групп (типов) в составе детрита. Нами изучались мшанки, брахиоподы, моллюски, трилобиты и иглокожие.

Количественные данные о макрофоссилиях $(\boldsymbol{A}, \boldsymbol{B}$ и $\boldsymbol{B})$ и детрите $(\boldsymbol{\Gamma}, \boldsymbol{Z}, \boldsymbol{E})$ в йыхвиском $\left(D_{I}\right)$ и кейласком $\left(D_{I I}\right)$ горизонтах разреза скв. Рапла

\begin{tabular}{|c|c|c|c|c|c|c|c|c|c|c|c|c|}
\hline \multirow{3}{*}{ 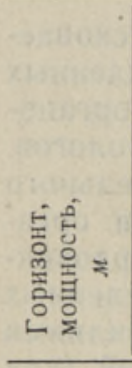 } & \multirow{3}{*}{ Ряд } & \multirow[b]{2}{*}{ 雍 } & \multicolumn{2}{|c|}{$\begin{array}{l}\text { Брахио- } \\
\text { поды }\end{array}$} & \multicolumn{3}{|c|}{ Моллюски } & \multirow[b]{2}{*}{ 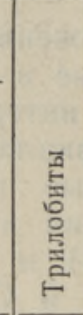 } & \multirow[b]{2}{*}{ 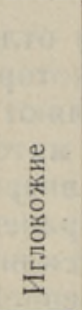 } & \multirow[b]{2}{*}{$\begin{array}{l}\text { 편 } \\
\text { ס } \\
\vdots \\
0 \\
0 \\
0 \\
0\end{array}$} & \multirow[b]{2}{*}{ 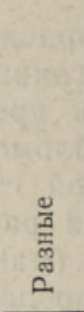 } & \multirow{3}{*}{ 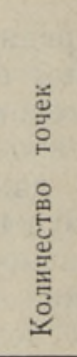 } \\
\hline & & & 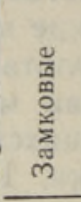 & 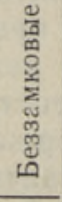 & 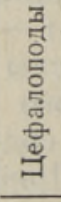 & 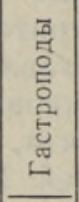 & 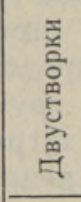 & & & & & \\
\hline & & $i_{1}$ & $i_{2}$ & $i_{3}$ & $i_{4}$ & $i_{5}$ & $i_{6}$ & $i_{7}$ & $i_{8}$ & $i_{9}$ & $i_{10}$ & \\
\hline $\mathrm{D}_{\mathrm{I}} ; 4,2$ & $\begin{array}{l}A \\
B \\
B \\
\Gamma \\
\not \\
E\end{array}$ & $\begin{array}{c}23 \\
2,7 \\
21 \\
117 \\
3,6 \\
17,1\end{array}$ & $\begin{array}{l}18 \\
2,1 \\
17 \\
50 \\
1,5 \\
7,3\end{array}$ & $\begin{array}{l}1 \\
0,1 \\
1 \\
-\end{array}$ & $\begin{array}{l}1 \\
0,1 \\
1 \\
-\end{array}$ & $\begin{array}{l}2 \\
0,2 \\
2 \\
-\end{array}$ & - & $\begin{array}{c}7 \\
0,8 \\
7 \\
228 \\
7,0 \\
33,4\end{array}$ & $\begin{array}{c}18 \\
2,1 \\
17 \\
218 \\
6,7 \\
31,9\end{array}$ & $\begin{array}{c}14 \\
1,7 \\
13 \\
-\end{array}$ & $\begin{array}{c}23 \\
2,7 \\
21 \\
70 \\
2,1 \\
10,3\end{array}$ & 3253 \\
\hline $\mathrm{D}_{\mathrm{II}} ; 19,1$ & $\begin{array}{l}A \\
B \\
B \\
\Gamma \\
\not \\
E\end{array}$ & $\begin{array}{c}102 \\
2,7 \\
18 \\
582 \\
3,7 \\
17,7\end{array}$ & $\begin{array}{c}149 \\
3,9 \\
26 \\
533 \\
3,4 \\
16,3\end{array}$ & $\begin{array}{l}7 \\
0,2 \\
1 \\
-\end{array}$ & - & $\begin{array}{l}21 \\
0,6 \\
4 \\
3 \\
0,02 \\
0,1\end{array}$ & $\begin{array}{c}4 \\
0,1 \\
1 \\
308 \\
2,0 \\
9,4\end{array}$ & $\begin{array}{c}61 \\
1,6 \\
11 \\
780 \\
4,9 \\
23,8\end{array}$ & $\begin{array}{c}188 \\
2,3 \\
14 \\
669 \\
4,2 \\
20,4\end{array}$ & $\begin{array}{c}36 \\
0,9 \\
6 \\
101 \\
0,6 \\
3,1\end{array}$ & $\begin{array}{c}101 \\
2,7 \\
18 \\
304 \\
2,0 \\
9,4\end{array}$ & 15779 \\
\hline
\end{tabular}

$A$ - количество образцов, содержащих макроостатки данной группы ( $i_{1}, i_{2}$ и т. д.) ископаемых организмов; $E-$ количественное распределение на- $0,5 M$ вертикального разреза; $B$ - групповой состав макроостатков, \% $(A i / \Sigma A i \cdot 100) ; \Gamma-$ количество изученных точек детрита данной группы ( $i_{1}, i_{2}$ и т. д.) ископаемых организмов в шлифах; Д - содержание детрита в составе породы, \% $(N / \Gamma i \cdot 100)$, где $N-$ общее количество изученных точек в шлифах; $E-$ групповой состав детрита, $\%$ $(\Gamma i / \Sigma \Gamma i \cdot 100)$.

Анализ распределения остатков ископаемых организмов и их детрита проводился погоризонтно - с азериского ( $\left.\mathrm{C}_{\mathrm{I}}\right)$ по раквереский (Е) включительно. По числу образцов (ряд $A$ в таблице) вычислены количественное распространение макроостатков отдельных групп организмов (ряд 5$)$ и их групповой состав в каждом горизонте (ряд $B$ ). При достаточно детальном изучении разрезов применяемый способ дает возможность демонстрировать общие тенденции распределения отдельных групп фауны.

* Нестор В. В., Нестор Х. Э., Пылма Л. Я., Хинтс Л. М., Эйнасто Р. Э. Фациальные модели среднеордовикских и лландоверийских бассейнов Прибалтики. 1976. (Рукопись в Центральном научном архиве АН ЭССР). 

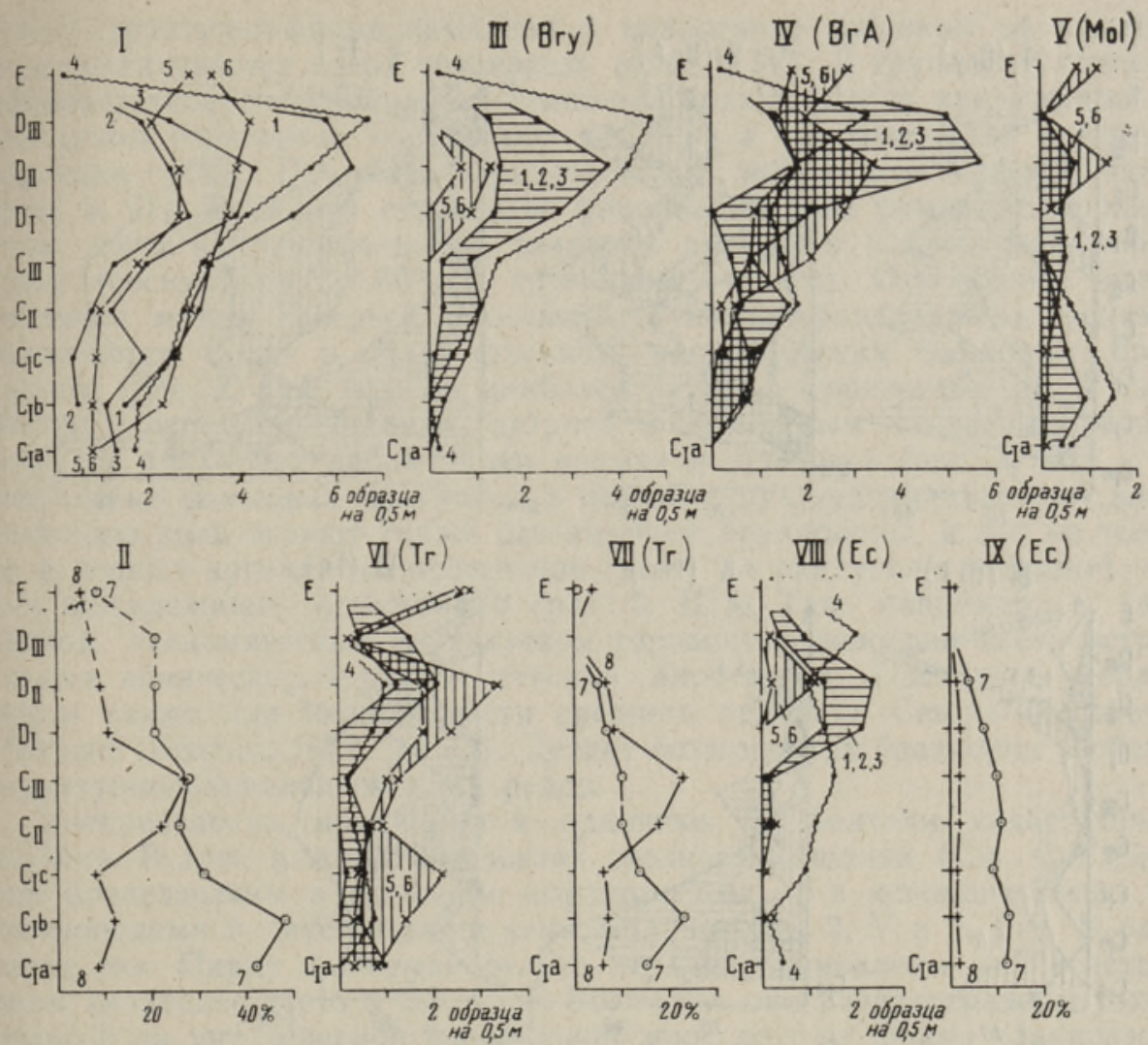

Рис. 2. Количественная характеристика фактического материала (погоризонтно). I - частота отобранных образцов; II - содержание органогенно-обломочного материала в породе; III-VI и VIII - количественное распространение мшанок (Bry), замковых брахиопод (BrA), моллюсков (Mol), трилобитов ( $\mathrm{Tr}$ ) и иглокожих (Ec); VII и IX - содержание трилобитового и иглокожевого детрита в породе. 1 - данные по макроостаткам в разрезе скв. Кыргессааре, 2 - то же в скв. Хаапсалу, 3 - то же в скв. Рапла, 4 - то же в скв. Пярну (переходная полоса), 5 - то же в скв. Энгуре, 6 - то же в скв. Кандава, 7 - содержание детрита в скв. Рапла, 8 - то же в скв. Энгуре. Полоса с горизонтальной штриховкой показывает вариацию количественных данных по разрезам скв. Кыргессааре, Хаапсалу и Рапла (северная структурно-фациальная зона), полоса с вертикальной штриховкой - то же по разрезам скв. Энгуре и Кандава (осевая структурнофациальная зона).

По вертикали горизонты: $\mathrm{C}_{1} \mathrm{a}-$ азериский, $\mathrm{C}_{\mathrm{I}} \mathrm{b}-$ ласнамягиский, $\mathrm{C}_{1 \mathrm{c}}-$ ухакуский, $\mathrm{C}_{I I}$ - кукрузеский, $\mathrm{C}_{\mathrm{III}}$ - идавереский, $\mathrm{D}_{\mathrm{I}}$ - йыхвиский, $\mathrm{D}_{\mathrm{II}}$ - кейлаский (включительно блиденская свита), $\mathrm{D}_{\mathrm{III}}$ - оандуский, E - раквереский. По горизонтали: количество образцов на 0,5 м (I, III-VI, VIII); содержание детрита (\%) в породе (II, VHI, XI).

Детрит изучен методом подсчета точек в шлифах из кернов буровых скв. Энгуре и Рапла (Пылма, 1972а, б). При этом содержание детрита данной группы в составе породы (ряд Д в таблице) характеризует количественное распространение детрита отдельных групп организмов.

Содержание скелетных остатков организмов в среднеордовикских отложениях увеличивается вверх по разрезу. Это относится также к частоте находок макрофоссилий (увеличивается вверх по разрезу) (рис. 2, I). В нижней и средней частях среднего ордовика (до йыхви- 


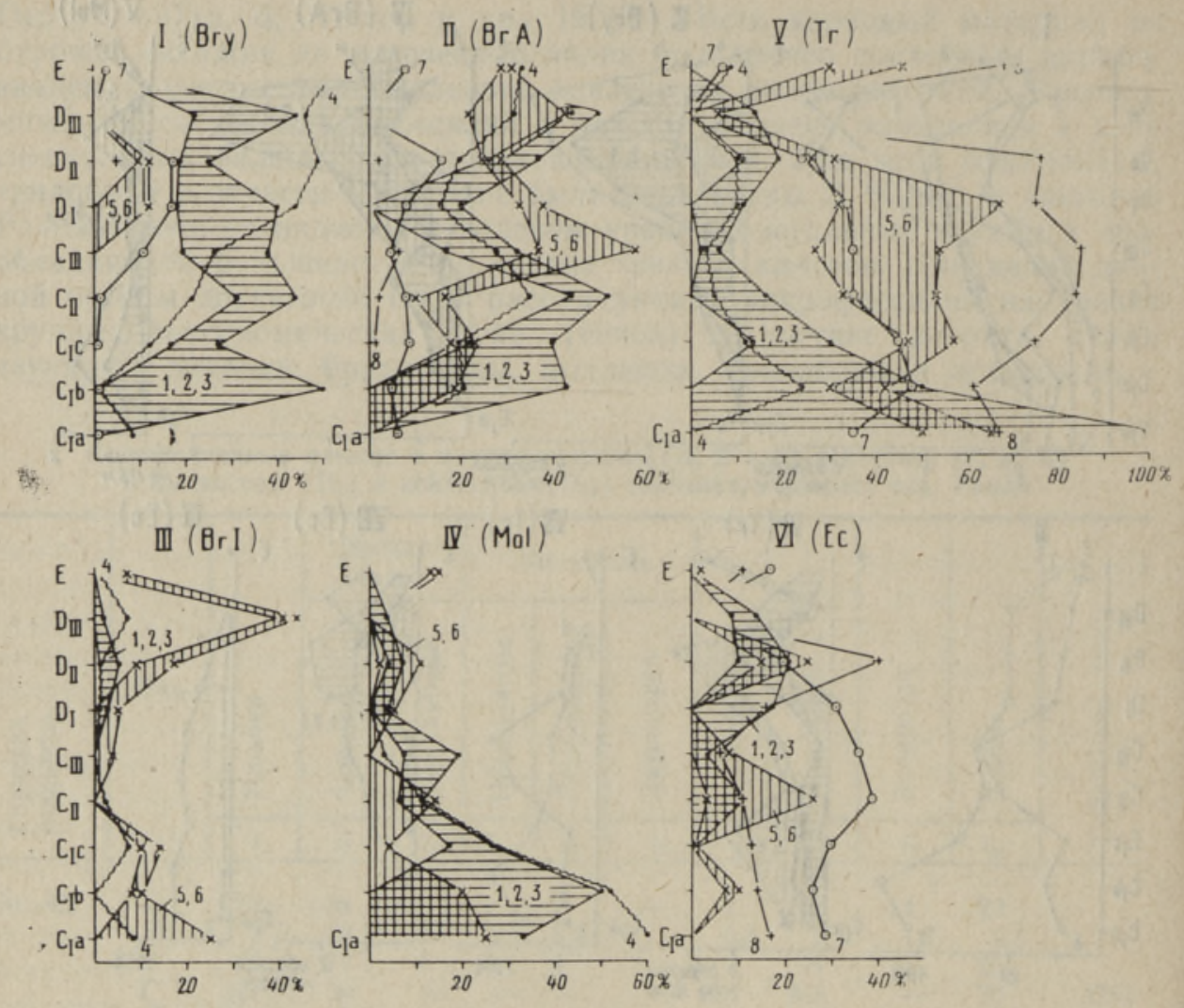

Рис. 3. Групповой состав остатков ископаемых организмов (по горизонтам): I мшанки и их детрит, II - замковые брахиоподы и их детрит, III - беззамковые брахиоподы, IV - моллюски, V - трилобиты и их детрит, VI - иглокожие и их детрит. Объяснения для $I-8$ см. на рис. 2.

ского горизонта включительно) это обусловлено прежде всего увеличением таксономического разнообразия (см. Мянниль и др., 1966; Рыымусокс, 1967), а в верхней части - существенным скоплением экземпляров отдельных видов.

Во всех рассматриваемых разрезах северной структурно-фациальной зоны и переходной полосы (см. рис. 1) значение мшанок увеличивается вверх по разрезу до кейлаского горизонта (DII). При этом количество мшанок в йыхвиском (DI), кейласком и оандуском (D горизонтах значительно превышает количество их во всех нижележащих горизонтах (рис. 2, III). В скв. Рапла в этих трех горизонтах отмечено наибольшее содержание мшанкового детрита как в составе породы (таблица, ряд Д), так и в групповом составе детрита (рис. $3, \mathrm{I})$. В групповом составе макрофоссилий мшанки имеют довольно одинаковое значение, начиная c ухакуского горизонта ( $\mathrm{C}_{\mathrm{I}} \mathrm{c}$, рис. 3, I). В осевой структурно-фациальной зоне первые единичные находки мшанок происходят из кукрузеского горизонта (C Икла, Дзербене). В йыхвиском и кейласком горизонтах их количество заметно увеличивается (скв. Кандава). Детрит мшанок (не более $1 \%$ как по частоте, так и по содержанню) установлен в скв. Энгуре в горизонтах $\mathrm{C}_{\mathrm{I}} \mathrm{c}-\mathrm{C}_{\mathrm{II}}$ и $\mathrm{D}_{\mathrm{I}}, \mathrm{D}_{\mathrm{II}}$.

Замковые брахиоподы весьма характерны для среднего ордовика 
обенх структурно-фациальных зон и аналогично мшанкам их количество увеличивается вверх по разрезу (рис. 2, IV). В групповом составе макроостатков северной зоны замковые брахиоподы в кукрузеском и оандуском горизонтах составляют до $50 \%$, а средняя часть среднего ордовика ( $\left.\mathrm{C}_{\mathrm{III}}, \mathrm{D}_{\mathrm{I}}\right)$ характеризуется их небольшим содержанием (рис. 3, II). В осевой структурно-фациальной зоне замковые брахиоподы достигают наибольшего значения именно в идавереском горизонте (составляют до $60 \%$ в групповом составе). Отмеченные выше различия между северной и осевой структурно-фациальными зонами выявляются также в количественном распределении замковых брахиопод (рис. 2, IV), причем наиболее четко в горизонтах $\mathrm{C}_{\mathrm{II}}$ и $\mathrm{C}_{\mathrm{III}}$. Между групповым составом детрита и групповым составом макроостатков брахиопод наблюдается прямая корреляция (рис. 3 , II).

Помимо замковых брахиопод в осевой структурно-фациальной зоне заметную роль играют также беззамковые брахиоподы, и это не только в черных аргиллитах моссенской свиты (=оандуский горизонт), но и в нижележащих отложениях (рис. 3, III). Так, например, в азериском, ласнамягиском и ухакуском горизонтах довольно часто встречаются конические брюшные створки акротретид. Последние характерны также для нижней части среднего ордовика Северо-Восточной Польши (Biernat, 1972, рис. 2). Детрит беззамковых брахиопод в обеих структурно-фащиальных зонах редок.

Распределение моллюсков в ордовике Прибалтики недостаточно изучено. В трех нижних горизонтах среднего ордовика ( $\left.\mathrm{C}_{\mathrm{I}} \mathrm{a}, \mathrm{C}_{\mathrm{I}} \mathrm{b}, \mathrm{C}_{\mathrm{I}} \mathrm{c}\right)$ они представлены в основном цефалоподами, а в лежащих выше гастроподами и двустворками (см. таблицу, рис. 2, V и 3 , IV). В разрезах скв. Пярну и Эйамаа от $\mathrm{C}_{\mathrm{Ia}}$ до $\mathrm{C}_{\mathrm{III}}$ установлены микрогастроподы (наиболее часто в $\mathrm{C}_{\mathrm{I}} \mathrm{b}, \mathrm{C}_{\mathrm{I}} \mathrm{c}$ ). Возможно они распространены узкой полосой на юге северной фациальной зоны до о-ва Эланд (Jaanusson, 1960). Содержание моллюсков в составе детрита уступает содержанию замковых брахиопод и мшанок, оно относительно высокое только в скв. Рапла - в ухакуском $(4 \%)$ и кейласком $(9 \%)$ горизонтах. В скв. Энгуре детрит моллюсков обнаружен только в интервале $\mathrm{C}_{\mathrm{T}} \mathrm{a}-\mathrm{C}_{\mathrm{II}}$, причем не более $1,6 \%$ (в $\left.\mathrm{C}_{\mathrm{I}} \mathrm{c}\right)$.

В отличие от рассматриваемых выше групп организмов трилобиты и иглокожие составляют основную массу детрита, содержащегося в среднеордовикских отложениях. Трилобиты наиболее часто встречаются в осевой структурно-фациальной зоне, но, как и в северной зоне и в переходной полосе, их относительно большое количество наблюдается в средней части среднего ордовика $\left(\mathrm{C}_{\mathrm{II}}, \mathrm{C}_{\mathrm{III}}\right.$; рис. $\left.2, \mathrm{VI}\right)$. В то же время в скв. Энгуре в этой части разреза отмечается наибольшее содержание трилобитового детрита как в составе породы $\left(18 \%\right.$ в $\mathrm{C}_{\mathrm{II}}$, $23 \%$ в $\mathrm{C}_{\mathrm{III}}$; рис. 2, VII), так и в групповом составе детрита (соответственно 84 и $85 \%$; рис. $3, \mathrm{~V})$. В разрезе скв. Рапла содержание трилобитового детрита уменьшается постепенно вверх по разрезу, начиная с ласнамягиского горизонта (рис. $3, \mathrm{~V}$ ).

Распределение иглокожих до сих пор мало изучено. В разрезах северной структурно-фациальной зоны встречаются в основном разрозненные фрагменты скелетов криноидей, цистоидей и других, которые наиболее часты в йыхвиском и кейласком горизонтах (рис. 2, VIII). В осевой зоне и переходной полосе (в скв. Энгуре, Стури, Кандава, Лаэва, Ныва, Каагвере, Отепя) кукрузеский и идавереский горизонты характеризуются частыми находками Echinosphaerites (биофация Echinosphaerites, по Мянниль, 1966). Следует отметить, что в шведских разрезах, например, в известняке Далбю, наблюдается уве- 


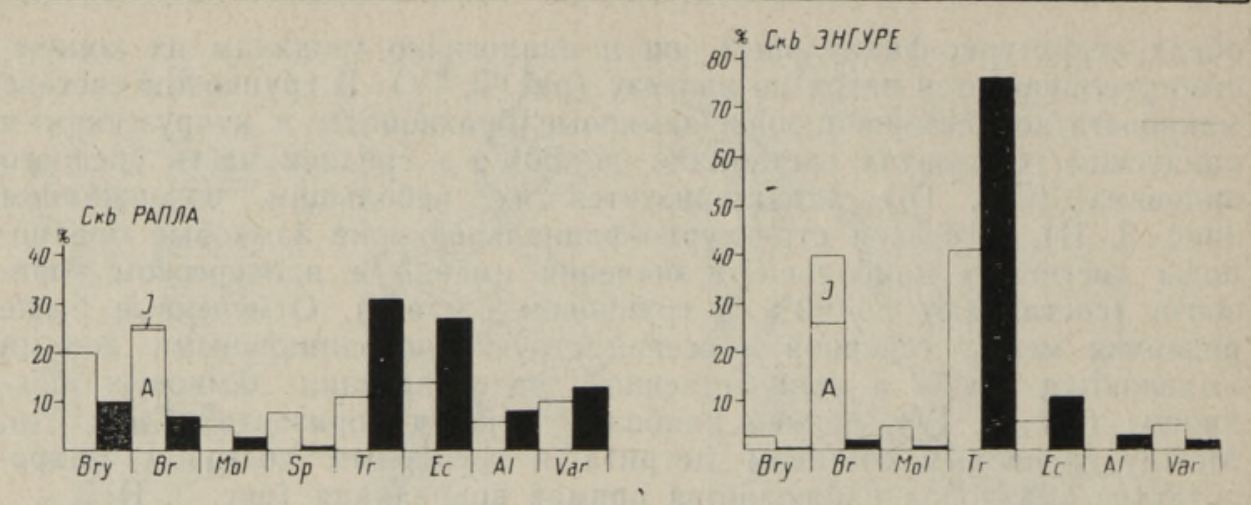

Рис. 4. Групповой состав остатков ископаемых организмов в среднем ордовике разрезов скв. Рапла и Энгуре (белые столбики - по макроостаткам, черные - по детриту). Вrу - мшанки, Br - брахиоподы, А - замковые, I - беззамковые, Mol - моллюски, Tr - трилобиты, Sp - губки (Pyritonema), Ес - иглокожие, $\mathrm{Al}$ - водоросли, Var - разные, в том числе граптолоидеи (по макроостаткам), остракоды и неопределяемые остатки в составе детрита.

личение значения цистоидей (в том числе и Echinosphaerites) в составе фауны на уровне этого же стратиграфического интервала (Jaanusson, 1976). В то же время с этим интервалом $\left(\mathrm{C}_{\mathrm{II}}, \mathrm{C}_{\mathrm{III}}\right)$ связано некоторое уменьшение значения трилобитов. Содержание фрагментов иглокожих в составе среднеордовикских пород не превышает $15 \%$ в скв. Рапла и $5 \%$ в скв. Энгуре (рис. 2, IX). В групповом составе детрита они достигают наибольшего значения $(30-40 \%)$ в скв. Рапла в $\mathrm{C}_{\mathrm{II}}, \mathrm{C}_{\mathrm{III}}$ и $\mathrm{D}_{\mathrm{I}}$ (рис. $3, \mathrm{VI}$ ).

Остальные группы ископаемых организмов, установленные в среднеордовикских отложениях, в составе фауны имеют меньшее значение. Следует, однако, отметить, что в северной структурно-фациальной зоне в некоторых горизонтах $\left(\mathrm{C}_{\mathrm{III}}-\mathrm{D}_{\mathrm{I}}, \mathrm{E}\right)$ существенную роль играют водоросли. Наиболее характерны они для скрытокристаллических известняков раквереского горизонта, где содержание водорослевого детрита достигает $59 \%$ (скв. Рапла).

Представленный выше материал показывает, что данные о распространении и групповом составе детрита среднеордовикских отложений Прибалтики имеют прямую или обратно пропорциональную связь с соответствующими данными по макрофоссилиям. При сравнении количественных данных прежде всего бросается в глаза, что некоторые группы организмов (мшанки, брахиоподы и моллюски) имеют существенное значение в составе макрофауны, в то время как их фрагменты в составе детрита относительно редки. Другие же группы (трилобиты, иглокожие и, по-видимому, также водоросли) составляют основную массу детрита, несмотря на то что количественное распределение их представителей в составе макрофоссилий может быть незначительным (рис. 4). Групповой состав макро- и микроостатков указывает на то, что содержание детрита в породе зависит не только от физических, химических и биологических факторов среды осадконакопления, но и в значительной мере от морфологической специфики раковин представителей отдельных групп (для трилобитов характерна линька, кроме того, они, как и иглокожие, легко распадаются на части).

Общий характер распределения представителей отдельных групп организмов определен трансгрессивно-регрессивным развитием средне- 


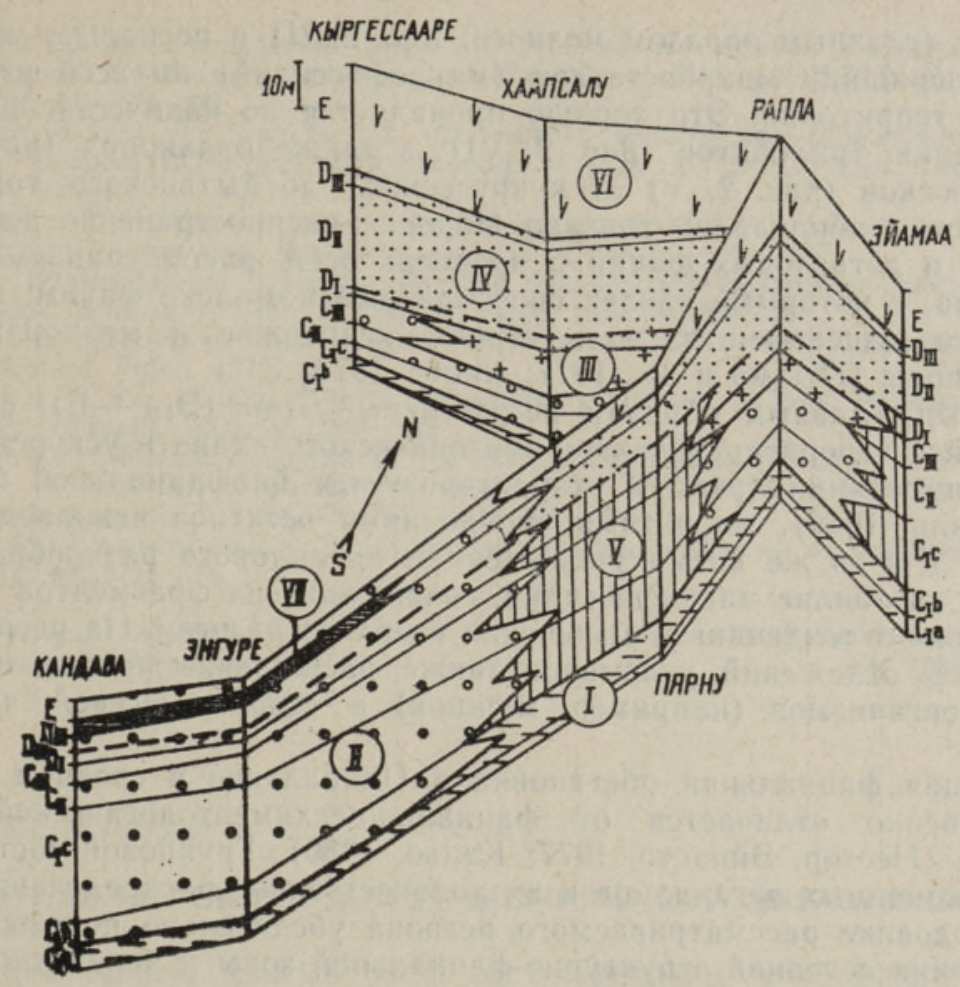

Рис. 5. Схема распространения среднеордовикских типов пород и включенных в них комплексов ископаемых организмов.

I - чистые и глинистые известняки с трилобитово-цефалоподовым комплексом, II - глинистые детритовые известняки, реже мергели с трилобитово-брахиоподовым комплексом, III - глинистые известняки с Pyritonema, IV - глинистые детритовые известняки и мергели с брахиоподово-мшанковым комплексом, V - детритовые известняки с брахиоподово-иглокожиевым комплексом, в нижних горизонтах с микрогастроподами, в верхних с мшанками, VI - скрытокристаллические известняки с водорослями, VII черные граптолитовые аргиллиты с безәамковыми брахиоподами. Условная граница между двумя этапам! седиментации показана прерывистой линией на границе горизонтов $\mathrm{D}_{\mathrm{I}} / \mathrm{D}_{\mathrm{II}}$. Вертикальный масштаб разрезов показан слева от разреза скв. Кыргессааре.

ордовикского Балтийского бассейна, фациальными условиями и направленностью климатических изменений. Таксономический состав и тенденция увеличения количества остатков ископаемых организмов вверх по разрезу свидетельствуют о продолжении трансгрессии в начале среднего ордовика $\left(\mathrm{C}_{\mathrm{I}} \mathrm{a}-\mathrm{C}_{\mathrm{I}} \mathrm{c}\right)$. Взаимные соотношения между распределением макроостатков и детрита и различия в этих соотношениях по разным структурно-фациальным зонам показывают, что в северной фациальной зоне в ходе детритообразования физические факторы среды имели бо́льшее значение, чем в осевой. Наиболее четко это проявляется на остатках трилобитов. Так, в горизонтах $\mathrm{C}_{\mathrm{I}} \mathrm{a}-\mathrm{C}_{\mathrm{I}} \mathrm{c}$ северной зоны содержание трилобитового детрита в породе (рис. 2, VII) заметно превышает таковое в осевой фациальной зоне, хотя именно в последней трилобиты имеют преобладающее значение в составе макрофоссилий, а также в групповом составе детрита (рис. $3, \mathrm{~V}$ ).

Этап стабилизации $\left(\mathrm{C}_{\mathrm{II}}-\mathrm{D}_{\mathrm{I}}\right)$ среднеордовикского Балтийского бассейна выражается в равномерном и относительно большом содержании 
детрита (главным образом мелкого; рис. 2, II) и несколько уменьшенном содержании макроостатков (макрофоссилий) по всей рассматрнваемой территории. Это хорошо проявляется по количественному распределению трилобитов (рис. 2, VI), а также брахиопод (рис. 2, IV) и моллюсков (рис. 2, V) от кукрузеского до йыхвиского горизонтов. C этапом стабилизации связано широкое распространение детритистоиловых и детритовых фаций в пределах всей рассматриваемой части бассейна, с которыми связан своеобразный комплекс фауны, в составе которого существенную роль играют иглокожие и мелкораковинные брахиоподы (Пылма и др., 1977; Хинтс, 1979).

Новый, главным образом регрессивный этап ( $\left.\mathrm{D}_{\mathrm{III}}-\mathrm{E}\right)$, сопровождающийся перераспределением тектонического плана и ускорением темпа седиментации (рис. 5), характеризуется биофациальной пестротой (Мянниль, 1966), массовыми скоплениями остатков ископаемых организмов и в то же время уменьшением их видового разнообразия. Несмотря на обилие макрофоссилий, содержание их фрагментов в составе пород имеет тенденцию уменьшения вверх по разрезу. На регрессивный характер отложений указывает также расширение ареала некоторых групп организмов (например, мшанок) в сторону осевой части бассейна.

Общая фациальная обстановка в Прибалтике в среднем ордовике существенно отличается от фациально-седиментологической модели силура (Нестор, Эйнасто, 1977; Кальо, 1980). Групповой состав остатков ископаемых организмов и их количественное распределение в среднем ордовике рассматриваемого региона убедительно показывают, что отложения северной структурно-фациальной зоны и переходной полосы относятся к сравнительно неглубокой части открытого шельфа, а отложения осевой структурно-фациальной зоны - к более глубокой его части (рис. 5).

\section{Л ИТ Е Р А Т У Р А}

А алоэ А. О. Зернистый компонент в силурийских отложениях Прибалтики по данным некоторых буровых скважин. - В кн.: Фации и фауна силура Прибалтики. Таллин, 1977, 45-55.

В инги с а а р П. Микролитологическое исследование известняков ордовикского разреза скважины Хаапсалу. - Изв. АН ЭССР. Хим. Геол., 1971, 20, 54-59.

К ала Э. А., М н с К. А., Ундрит с Л. А. Стратиграфическая характеристика разреза скважины Пярну. - Тр. Ин-та геол. АН ЭССР, 1962, Х, 19-31.

Кальо Д. Л. О силуре Прибалтики в качестве экостратиграфической модели. В кн.: Экостратиграфия и экологические системы геологического прошлого. (Тр. XXII сессии ВПО). Л., 1980, 30-37.

Мянни л ь Р. М. История развития Балтийского бассейна в ордовике. Таллин, 1966. М янни ль Р. Корреляция верхневируских отложений (средний ордовик) Швеции и Прибалтики по хитинозоям. - Изв. АН ЭССР. Хим. Геол., 1972, 21, 137142.

М янниль Р. М. Распределение граптолоидей в карбонатных отложениях ордовика Прибалтики. - В кн.: Граптолиты и стратиграфия. Таллин, 1976, 105-118.

М янниль Р. М., Р ы ы у сокс А. К., С а рв Л. И. О биостратиграфической характеристике ордовикской фауны Прибалтики. - В кн.: Палеонтологические критерии объема и ранга стратиграфических подразделений. (Tp. VIII сессии ВПО). М., 1966, 131-138.

Н есто р Х. Э., Э й н а с т о Р. Э. Фациально-седиментологическая модель силурийского палеобалтийского периконтинентального бассейна. - В кн.: Фации и фауна силура Прибалтики. Таллин, 1977, 89-121.

Пылм а Л. О переходной полосе между северной и осевой фациальными зонами ордовика Прибалтики. - Изв. АН ЭССР. Хим. Геол., 1967, 16, 272-275.

Пыл м а Л. Состав и количество детрита в отложениях осевой фациальной зоны ордовика Прибалтики (по скважине Энгуре). - Изв. АН ЭССР. Хим. Геол., 1972a, 21, 148-154. 
Пылма Л. Состав и количество детрита в отложениях северной фациальной зоны ордовика Прибалтики (по скважине Рапла). - Изв. АН ЭССР. Хим. Геол., $19726,21,326-332$.

Пылма Л., Сарв Л., Хин тс Л. Расчленение ордовикских отложений разреза скв. Берзини (Юго-Восточная Латвия). - Изв. АН ЭССР. Хим. Геол., 1977, 26, $113-121$.

Р ы м у сок с А. К. Стратиграфия вируской и харьюской серий (ордовик) Северной Эстонии. - Автореф. док. геол.-минерал. н. Тарту - М., 1967.

Х интс Л. Новые данные о распространении брахиопод в йыхвиском горизонте Северной Эстонии. - Изв. АН ЭССР. Геол., 1979, 28, 94-99.

Biernat, G. Ordovician Inarticulate Brachiopods from Poland and Estonia. Paleontol. Polon. 1972, 28.

J a a nusson, V. The Viruan (Middle Ordovician) of Olland. - Publ. Palaeontol. inst. univ. Uppsala, 1960, 38, 207-288.

Ja a nusson, V. Faunal dynamics in the Middle Ordovician (Viruan) of Baltoscandia. - In: The Ordovician System. Proc Palaeontol. Assoc. Symposium, Birmingham, Sept. 1974. Cardiff, 1976, 301-326.

S mosna, R., Wa rs ha uer, S. Fossil diversity in thin section. - J. Sediment. Petrol, $1978,48,331-336$.

Ннститут геологии

Академии наук Эстонской ССР
Поступила в редакцию 6/II 1981

\title{
Linda HINTS, L. POLMA
}

\section{KIVISTISTE JA DETRIIDI JAOTUS BALTIKUMI KESKORDOVIITSIUMIS}

Puursüdamikest pärineva materjali põhjal on iseloomustatud ja vōrreldud fossiilsete organismide skeletijäänuste (kivististe) ja nende detriidi esinemissagedust ning grupilist koostist Pōhja- ja Kesk-Baltikumi keskordoviitsiumi karbonaatkivimites. Ilmneb, et kivis. tistena küllalt arvukad sammalloomad, brahhiopoodid ja molluskid moodustavad detriidi üldhulgast suhteliselt väikese osa. Seevastu trilobiidid ja okasnahksed (osaliselt ka vetikad) annavad pōhilise osa detriidist.

Eri taksonoomilistesse gruppidesse kuuluvate kivististe ja nende detriidi vahekorrad viitavad sellele, et detriidi sisaldus kivimis ei sõltu ainult settimise füüsikalistest, keemilistest ja bioloogilistest teguritest, vaid suurel määral ka fossiilsete organismide morfoloogilistest iseärasustest. Muutused kivististe ja detriidi jaotuses ning grupilises koos. tises peegeldavad hästi Balti basseini pōhilisi arenguetappe keskordoviitsiumis, samuti erinevusi struktuurilis-fatsiaalsete vööndite vahel.

\author{
Linda HINTS, L. POLMA
}

\section{DISTRIBUTION OF MACROFOSSILS AND SKELETAL DEBRIS IN THE EAST BALTIC MIDDLE ORDOVICIAN}

Relative abundance and group composition of different macrofossils and their skeletal debris from Northern and Central East Baltic Middle Ordovician carbonate rocks (in borings) have been compared.

It is evident that the most frequent macrofossils such as bryozoans, brachiopods and molluscs are represented with a low percentage in total content of skeletal debris, which is formed mainly from relatively rare macrofossils, such as trilobites and echinoderms (partially algae).

The content of different macrofossil groups and their detrite allows to confirm that the composition of skeletal debris in sediments depends not only on physical and chemical factors and activity of organisms, but is also greatly influenced by the morphology and physiology of different fossil groups.

The changes in the relative abundance and group composition of studied macrofos. sils and their skeletal debris in the Middle Ordovician of East Baltic reflect the trends in the development of the Baltic basin as well as in the differences between its confacies belts. 